\title{
CORPORATE IMAGE AND REPUTATION AS DRIVERS OF CUSTOMER LOYALTY
}

\begin{abstract}
Prior research suggests that corporate image and reputation can contribute to relationship marketing and customer loyalty. However, little empirical evidence support the influence of these constructs on customer loyalty. This study investigates the influence of corporate image -comprised of functional and emotional aspects- and reputation on customer loyalty. A structural equation model is developed to test the research hypotheses. The study was tested using data collected from a sample of Spanish consumers in a service setting. Results show that functional and emotional image have a positive influence on corporate reputation. Similarly, corporate reputation has a positive influence on customer loyalty. This study may help managers use their resources more effectively by focusing on corporate image and reputation as the greatest strategic assets to enhance customer loyalty.
\end{abstract}

\section{Keywords}

Corporate image, corporate reputation, customer loyalty

\section{Introduction}

While some studies document a positive relationship between corporate image and reputation and financial performance (Fombrun 1996; Roberts and Dowling 2002) and try to explain their underlying mechanisms and consequences (Cretu and Brodie 2007; Dowling 2006; Keh and Xie 2009; Walsh and Wiedmann 2004), existing research in the marketing literature says little about whether corporate image and allied constructs such as corporate reputation can contribute to relationship marketing and customer loyalty. Many researchers in marketing have recognized the critical roles of corporate image and reputation in customers' buying behavior and their importance in developing and maintaining loyalty on the part of consumers (Dick and Basu 1994; Helm and Tolsdorf 2013; Nguyen and Leblanc 2001; Richard and Zhang 2012; Tu et al. 2013). Moreover, the concepts of corporate image and reputation have undergone a renaissance particularly because the interest of several academics such as Balmer and Greyser who devote great attention to the concept of "corporate marketing" a new paradigm based on an integrated approach to marketing at an institutional level (Balmer 2006; Balmer and Greyser 2003, 2006). However, a review of the research reveals little empirical evidence to support the influence of these constructs on customer loyalty (Weiwei 2007). Moreover, most of the studies have analyzed corporate image and corporate reputation separately. With regard to this, some authors have expressed a potential link between the two concepts although there is some confusion between both constructs (Abratt and Klein 2012; Gotsi and Wilson 2001; Melewar et al. 2012).

One way to distinguish between corporate image and reputation is to examine the different influences they have on the processes that create perceptions of customer 
loyalty for the company's products/services. Understanding the nature of these processes has received attention in marketing by both academics and practitioners in service markets (Cretu and Brodie 2007; Rust et al. 2004; Walsh et al. 2009). However, research in this area has given little explicit attention to distinguishing between the influences of corporate image and reputation. With this in mind, the objective of this study is to describe the relationship between corporate image and corporate reputation and their impact on customers' loyalty. The understanding of these relationships contributes to establish the distinction between image and reputation and to help managers use them more effectively in its communication strategies, thereby enhancing the firm's position.

To fulfill these objectives this article is organized as follows. The next section presents the literature review and the hypotheses development. Then, the research methodology is discussed, followed by the research results. The paper then presents a discussion of findings and their implications for managers. The paper ends with a presentation of limitations and suggestions for further research.

\section{Literature review and hypotheses development}

\subsection{Loyalty}

Understanding the processes that create customer loyalty is a fundamental issue in contemporary marketing because it provides the link between marketing and financial performance (Reichheld et al. 2000). Customer loyalty is supposed to have a positive impact on the performance of companies both at an aggregate level and at the individual customer level (Park 2006; Yeung and Ennew 2000). One of the most essential theories of loyalty marketing is that a small increase in loyal customers can lead to a significant increase in profitability to a business (Reichheld and Sasser 1990; Reichheld 1993). In their study in the service sector, Reichheld and Sasser (1990) found that a 5\% increase in customer retention resulted up to a $125 \%$ increase in profits. Moreover, it has been known that it is six times more expensive to plan marketing strategies to attract new customers than it is to retain existing customers (Petrick 2004).

Researchers have perceived and defined the concept of loyalty in a number of different ways. For instance, Oliver (1997 p. 392) has defined customer loyalty as "a deeply held commitment to rebuy or repatrionize a preferred product or service consistently in the future, despite situational influences and marketing efforts having the potential to cause switching behavior", whereas Lam et al. (2004 p. 294) understand this construct as " $a$ buyer's overall attachment or deep commitment to a product, service, brand, or organization". Similar definitions for the construct exist but much of the original research on customer loyalty defined it in behavioral and attitudinal terms. Precisely, a general approach to analyze customer loyalty is to differentiate between consumer's attitudinal and behavioral loyalty (Chaudhuri and Holbrook 2001; Uncles et al. 2003). The behavioral component of customer loyalty is related to repeated transactions made from the consumer in a specific period of time. However, repurchase behavior can be due to satisfaction or just to a lack of alternatives, or as a reason of convenience or 
habit. Therefore, it is thought that this approach can lead to identifying as loyalty some behaviors that have been usually described as "spurious loyalty" or even "no loyalty", which happen when the repurchase takes place even if the organization has a negative image in the market (Dick and Basu 1994 p. 100). On the other hand, attitudinal loyalty means that a positive evaluation of the company is made together with the existence of an emotional link between the consumer and the organization that generates a real loyalty or, at least, a potential loyalty. This type is linked to active loyalty, which not only means repurchase but also a positive word of mouth. However, a customer's favorable attitude toward a particular product or brand may not assure repeat patronage or repurchase frequency (Dick and Basu 1994; Oliver 1997). Thus, numerous researchers insist and agree that measuring both attitudinal and behavioral aspects is essential to assess customer loyalty precisely (Martínez and Rodríguez del Bosque 2013). Therefore, in this research loyalty is analyzed in terms of behavioral and attitudinal aspects.

\subsection{Corporate image}

Corporate image and allied constructs such as corporate reputation are defined and linked together in various ways. The term corporate image refers to the overall impression made on the minds of the public about an organization (Barich and Kotler 1991). Abratt (1989) similarly conceptualized corporate image as the feelings and beliefs about the company that exist in the mind of the audience. Image also strongly influences consumers' decision making processes and behaviors by offering mental shortcuts when processing purchase data (Kotler and Gertner 2002).

This construct is related to business name, architecture, variety of products/services, tradition, ideology, and to the impression of quality communicated by each employee interacting with the organization's clients (Nguyen and Leblanc 2002). Corporate image may be considered "as a function of the accumulation of purchasing/consumption experience overtime" (Andreassen and Lindestad 1988 p. 84) and seems to have two principal dimensions: (1) functional and (2) emotional (affective) (Kennedy 1977). The functional component is related to tangible attributes that can be easily measured. On the other hand, the emotional component is associated with psychological dimensions that are manifested by feelings and attitudes towards an organization. These feelings are derived from individual experiences with an organization and from the processing of information on the attributes that constitute functional indicators of image (Kennedy 1977). In the present study corporate image is analyzed in terms of these two dimensions since a differentiation between a functional and emotional part of the image of the firm is a common practice among researchers that will allow us to analyze in depth the relationship between corporate image, reputation and customer loyalty and make a greater contribution to the academy.

As Nguyen and Leblanc (2002 p. 243) state "an organization does not project a unique image". Actually, organizations may possess various images which differ according to specific groups such as customers, employees and shareholders, each of whom has 
different types of experiences and contacts with firms (Dowling 1988). Often related to symbols and values, the building of corporate image is a lengthy process which can be improved rapidly by technological breakthroughs and unexpected achievements or, conversely, destroyed by neglecting the needs and expectations of the various groups who interact with the organization (Dichter 1985). The early works on image theory suggested that an individual's behavior is based on a psychological or distorted representation of objective reality that exists in the individual's mind (Martineau 1958). Therefore, people's behaviors are more likely to be determined by an image than by objective reality. In service markets corporate image is expected to play an important role, especially since it is difficult to differentiate products or services based on tangible quality features (Mudambi et al. 1997).

\subsection{Corporate reputation}

The concept of corporate reputation draws academic attention from the management, economics, sociology and marketing areas (Berens and van Riel 2004; Walsh and Beatty 2007). In general, researchers conceptualize corporate reputation from either an economic perspective that regards corporate reputation as insiders' or/and outsiders' expectations and estimations of specific organizational attributes (Weigelt and Camerer 1988), or builds from institutional theory that characterizes corporate reputation as a global impression reflecting the perception of a stakeholder group (customers, employees, investors ...) (Fombrun and van Riel 1997). Consistent with the institutional view, in this study corporate reputation is interpreted as the overall perception of a company, what it stands for, what it is associated with and what individuals may expect when buying the products or using the company's services (Fombrun and Shanley 1990). Therefore, corporate reputation may be viewed as a mirror of the firm's history which serves to communicate to its target groups information regarding the quality of its products or services in comparison with those of its competitors (Yoon et al. 1993). Fombrun (1996) assigns the following key characteristics to the concept of corporate reputation: (1) a cognitive feature of an industry that crystallizes a company's perceived ranking in a field of other rivals, (2) it is created from the bottom up as each of us applies our own personal combination of economic and social, selfish and altruistic criteria in judging a company and its future prospects and (3) it is a snapshot that reconciles the multiple images of a company held by all its constituencies.

Past research indicates that corporate reputation has a positive effect on financial performance (Fombrun 1996). Additionally, a favorable corporate reputation can greatly benefit companies in other ways including (1) delaying rival mobility in the industry, (2) charging price premium on customers, (3) attracting higher-quality and larger amounts of investments from the stock market, (4) maintaining a high spirit among employees, (5) enjoying a cost advantage due to less contracting and monitoring costs with suppliers and lower remuneration rate among employees and (6) supporting and enhancing new product introduction and recovery strategies in the event of a crisis (Fombrun and Shanley 1990; Fombrun 1996; Fombrun et al. 2005; Rindova et al. 2005; Roberts and Dowling 2002). To conclude, Helm (2005 p. 106) believes that the 
understanding of the reputation construct "has been dominated by research focused on the construct itself [...] inclusion of reputation in structural equation modelling in order to examine its interplay with other constructs has remained scarce". Similarly, as Walsh and Beatty (2007 p. 127) emphasize "previous studies have mainly focused on identifying sources of reputation while the potential consequences of corporate reputation have received less attention". Consequently, the analysis of the relationship between corporate reputation, image and customer loyalty is considered a contributing source to the marketing literature.

\subsection{Corporate image and reputation as antecedents of customer loyalty}

Prior to analyze the influence of corporate image and reputation on customer loyalty, it is considered necessary to explore the relationship between both concepts. A review of the past research shows little empirical results (Weiwei 2007). For instance, Porter (1985) proposes that a good reputation may help a pioneer company building an innovative image in the industry. Franklin (1984) states that corporate reputation is a global and final outcome of the process of building corporate image. Similarly, Dutton et al. (1994) argue that corporate reputation represents outside members' perception of corporate image. In order to differentiate between both concepts Gotsi and Wilson (2001) distinguish two different schools of thought: (1) the analogous school of thought, which views corporate reputation as synonymous with corporate image, and (2) the differentiated school of thought, which considers the terms to be different and, according to the majority of the authors, interrelated. This research is part of the differentiated school as it is the most contemporary view with the largest representation in the academic literature.

Following the differentiated school of thought corporate reputation is a snapshot that reconciles the multiple images of a company held by all its constituencies (Fombrun 1996). Therefore, corporate image and reputation are the results of an aggregation process which incorporates diverse information used by the consumer to form a perception of the firm (Nguyen and Leblanc 2001). Even for a consumer who has not yet had experience with the company, these perceptions may be formed from other sources of information such as corporate communications. According to Nguyen and Leblanc (2001 p. 229) "the emotional component of corporate image and corporate reputation may share a close relationship because of the psychological dimensions which contribute to their formation". According to these authors, in the case of services that are categorized as experience products whose quality can only be evaluated after consumption, given their intangibility, corporate image and reputation both can be used as effective means of predicting the outcome of the service production process and considered as the most reliable cues which signal the ability of a service company to satisfy the customer's desires.

From the marketing perspective the impact of corporate image and reputation on consumer behavior is well recognized (Cretu and Brodie 2007; Dowling 2006; Keh and Xie 2009; Nguyen and Leblanc 2001; Richard and Zhang 2012; Rindova et al. 2005; 
Walsh and Wiedmann 2004; Wang et al. 2003; Yoon et al. 1993). Loyalty is supposed to be positively affected by favorably perceived images (Rindova and Fombrun 1999). Thus, both corporate image and reputation are assumed to have positive effects on customer loyalty. Numerous authors assert that a good corporate image or reputation helps to establish and maintain a loyal relationship with customers (Andreassen and Lindestad 1998; Dick and Basu 1994; Helm and Tolsdorf 2013; Tu et al. 2013; Walsh et al. 2009). Zinkhan et al. (2001) argue that when customers, among other stakeholders, interact with a firm they often lack the capacity and inclination to gather accurate information about it. A firm's image and reputation then becomes a surrogate indicator of the quality of products or services. As Wang et al. (2003 p. 76) argue, image and reputation "play an especially important strategic role in service markets because then repurchase evaluation of service quality is necessarily vague and incomplete". It can be argued that corporate image and reputation are particularly important in credence services which are notably difficult for customers to evaluate (Hardaker and Fill 2005). Due to their intangibility, the quality of services may be more difficult to evaluate by consumers and thus, service firms may be more likely to feel the effects of image and reputation than other types of companies (Fombrun 1996). Consequently, since the exact relationship between image and reputation is still unknown, it is relevant to examine the interactions between the constructs. Hence, and based on the previous literature review we propose:

$\mathbf{H}_{1}$ : Functional image will positively influence corporate reputation.

$\mathbf{H}_{2}$ : Emotional image will positively influence corporate reputation.

$\mathbf{H}_{3}$ : Corporate reputation will positively influence customer loyalty.

$\mathbf{H}_{4}$ : Functional image will positively influence customer loyalty.

H5: Emotional image will positively influence customer loyalty.

\section{Methodology research}

\subsection{Sample}

In order to test the hypothesis personal surveys of hotel customers were conducted in Spain. To design the research sample a non-probability sampling procedure was chosen (Trespalacios et al. 2005). Specifically, a convenience sample was used. Nevertheless, in order to guarantee greater representation of the data the sample was generated by applied quota sampling as this technique provides a sample structure similar to that of the population. Specifically, we used two criteria relevant to the investigation: the gender and the age of respondents. From the target sample of 400 questionnaires, 382 questionnaires were completed. The fieldwork was carried out in April 2011. Respondents were instructed to refer national (Spanish) hotels where they had spent their last holidays in the last year when answering questions regarding the variables integrated in the model. Specifically, hotels in Spain were chosen to provide the context for this research for two key reasons. First, Spain is considered to be amongst 
the leading countries internationally in the field of tourism and hospitality (UNWTO 2009), in which hotels occupy an important position (INE 2012). Secondly, Spanish hotels operate within an extremely competitive market. Customers are able to choose their level of loyalty to the hotel, such that if they are dissatisfied with a hotel company, they can cease to deal with it as there are many alternatives. Given that they can identify better offers from competing firms (Bigné et al. 2000) this emphasizes the importance to hotels of carrying out activities that contribute to winning customer loyalty in the sector.

\subsection{Measurement instrument}

To measure corporate image, reputation and customer loyalty, scales validated by the literature were used. Functional and emotional image were measured using the scale validated by Carrasco et al. (2008). Corporate reputation was measured with four items developed by Ahearne et al. (2005). Finally, customer loyalty measure was drawn from extant services literature (Sirdeshmuhk et al. 2002; Zeithaml et al. 1996) and included four items measuring both the attitudinal and behavioral components of loyalty. Before the questionnaire was finalized an academic professional in the hospitality industry and two professors who are familiar with the subject of this study reviewed the questionnaire to assure content validity. Minor revisions were made based on their suggestions. Subsequently, a pilot study was conducted to ensure the reliability of each construct, using a convenience sample of 28 postgraduate students. The final measures are provided in the Appendix.

\subsection{Data analysis}

Based on Anderson and Gerbing's (1988) two-step approach, the current study assessed the adequacy of measurements using a confirmatory factor analysis (CFA) and tested the hypothesized relationships by employing a structural equation modeling (SEM).

\section{Results}

\subsection{Confirmatory factor analysis results}

First of all, the psychometric properties of the CFA undertaken for the proposed scales were estimated using the maximum likelihood method. The overall goodness-of-fit indices of CFA (Table 1) show that all the fits in the measurement model are acceptable. The incremental fit index (IFI), the comparative fit index (CFI), the non-normed fit index (NNFI), and the normed fit index (NFI) all exceed, or were close to, 0.90 (Bentler 1992). Moreover, the root mean square error of approximation (RMSEA) was smaller than 0.08 (Bentler and Bonett 1980). In order to verify that all items used were adequate measures of their respective latent constructs, their reliability and validity had to be confirmed. This was achieved by analyzing the individual reliability coefficient $\left(R^{2}\right)$ of each item, Cronbach's alpha coefficient and the variance extracted (Hair et al. 2010). The individual reliability showed a value greater than, or close to, the minimum acceptable limit which is 0.50 (Hair et al. 2010). Furthermore, Cronbach's alpha 
coefficient and variance extracted were close to, or above, the reference value, at 0.70 and 0.50 , respectively (Hair et al. 2010) (Table 1).

The results obtained led us to conclude that the set of first-order dimensions proposed to measure the proposed set of constructs were valid. As regards the second-order construct -corporate image-, Table 1 presents the Cronbach's alpha coefficient and the variance extracted. It can be seen that the scales for "Functional image" and "Emotional image" offered individual reliability levels above 0.50. Similarly, the Cronbach's alpha coefficient and variance extracted values were above, or close to, the minimum acceptable, confirming the internal consistency. We then proceeded to calculate the value of each of the variables in the model. These values enabled us to calculate the interactions between corporate image, reputation, and customer loyalty. Finally, in order to test the dependency between corporate image and corporate reputation, a $\chi^{2}$ test was performed. The results indicate a significant interdependence between corporate image and corporate reputation $(\mathrm{p}<0.005)$.

\section{Table 1 here}

\section{Figure 1 here}

\subsection{Structural model}

A structural model was estimated to test Hypotheses 1-5. The NFI gave a value of 0.90 and the RMSEA value was acceptable (0.08) (Figure 1). The incremental fit measurements CFI (0.91), IFI (0.92) and NNFI (0.90) were also acceptable. In its totality, the fit of the model can be said to be acceptable (Figure 1). On the basis of these results, the following aspects are worthy of note. Functional image has a significant influence on both corporate reputation $\left(\beta=0.559^{*}, \mathrm{p}<0.00\right)$ and customer loyalty $\left(\beta=0.311^{*}, p<0.00\right)$. Therefore, $\mathrm{H}_{1}$ and $\mathrm{H}_{4}$ find empirical support. Similarly, emotional image has a significant influence both on corporate reputation $\left(\beta=0.301^{*}\right.$, $\mathrm{p}<0.00)$ and customer loyalty $\left(\beta=0.265^{*}, \mathrm{p}<0.00\right)$. Therefore, $\mathrm{H}_{2}$ and $\mathrm{H}_{5}$ find empirical support. Finally, corporate reputation has a significant influence on customer loyalty $\left(\beta=0.414^{*}, \mathrm{p}<0.00\right)$. Therefore, $\mathrm{H}_{3}$ has empirical support.

\section{Conclusions and managerial implications}

Gaining customer loyalty constitutes the final ambition of many companies since loyal customers buy more, spend a larger share of their incomes at the supplier and tend to be less price-sensitive than other customers. The main contribution of the present study lies in its examination of the process of generating customer loyalty using the constructs of corporate image - functional and emotional- and reputation. By considering the image of a firm (understood as a multidimensional concept composed of functional and emotional aspects) with the notion that corporate reputation is an important construct for understanding consumer behavior (Nguyen and Leblanc 2001; Keh and Xie 2009; Walsh et al. 2009), this research suggest a framework to delve into customer loyalty. The results of our analysis indicate that corporate reputation and customer loyalty are 
built on corporate image both functional and emotional. This study demonstrates that companies that are able to improve their perceived image will be in a better position to increase corporate reputation and built customer loyalty. It is worth noting the positive effect that functional and emotional image have on corporate reputation and customer loyalty, these being new findings in the service context. Additionally, this paper indicates that customers perceive corporate image and reputation as two distinct constructs. These results are consistent with previous researches such as the papers by Helm and Tolsdorf (2013), Richard and Zhang (2012) and Tu et al. (2013) among others, which point to both corporate image and reputation as strategic assets that are appropriate for generating not only an overall evaluation of firms but also for arousing affective positive perceptions of service performances thus increasing loyalty on the part of customers. Therefore, we agree with Nguyen and Leblanc (2001) who argue that reputation can be used as an effective means of predicting the outcome of the serviceproduction process and can be considered the most reliable indicator of the ability of a service firm to satisfy customers' desires.

Secondly, the present study offers managers specific guidelines as to the content they should include in their offer in order to increase both corporate reputation and customer loyalty. Given the positive influence of corporate image on reputation and customer loyalty managers should: provide a positive functional image related to tangible attributes that can be easily measured such as facilities, location or staff attention. This might include personalized customer service and actions that facilitate the customer's experience of buying the products/services. On the other hand, we encourage managers to provide and affective or emotional image of the company in the form of emotional and social elements. For instance, managers could consider aspects of corporate personality that can lead to a favorable attitude on the part of consumers such as an ethical behavior, develop social and cultural initiatives, or provide a fair treatment to employees. Moreover, managers need to pay particular attention to these variables each time a customer consume the products/services of the firm, as they will ultimately impact on the firm's capacity to attract and retain customers.

In a similar way, since this study prove the direct impact of corporate reputation on customer loyalty and given that a firm's reputation serve as a quality promise for customers, hotel managers should continually focus on serving their customers with high quality products and services with integrity and honesty. Furthermore, given that our results suggest that when customers perceive a company as reputable they report a higher level of loyalty managers should assess and monitor corporate reputation on a regular basis to take appropriate corrective actions. Regarding corporate communications the findings of this study suggest that managers should emphasize and coordinate elements of corporate image which is strongly significant in the creation of a favorable reputation. Managers should develop an integrated marketing communication strategy with multiple information channels to enhance corporate reputation and increase customer loyalty. For instance, hotel companies should use social media, direct mail, public relations and advertising to communicate the functional and emotional 
aspects of corporate image to customers. Specifically, hotel companies could participate in forums and events, increase their presence in social networks (e.g., Facebook, Twitter...) and use in-house advertisings (e.g., in-house magazines and television channels) in order to develop a favourable reputation.

Another implication for hotel companies is that customers often derive their sense of a company's image and reputation from their interaction with employees. This means that hotel firms should ensure that employees act in the way customers expect in order to increase not only company's reputation but also loyalty on the part of customers. Actions to ensure high levels of customer loyalty include staff training that will enable employees to help customers make satisfactory purchase decisions and have enjoyable interactions with the firm.

To conclude, the present research stands out the relevance of corporate image and reputation to achieve sustainable competitive advantages. In the authors' view, the effective assessment and management of corporate image and reputation should be an integral part of corporate strategies not only in the hotel sector but in other industries. The authors consider that this management will be improved when managers realize (and internalize) that the monitoring and evaluation of these intangible assets may help companies to reach a situation in which company's financial performance will benefit. By creating and developing a favorable corporate reputation firms can benefit from higher levels of differentiation, appeal to investors, the attraction of highly motivated employees, the willingness of customers to pay a premium price (Roberts and Dowling 2002) and, as previously demonstrated, higher levels of customer loyalty.

As with all empirical studies, this work has certain limitations which themselves constitute possible lines of research for the future. One important limitation is that only those variables considered to be the most relevant for achieving the study's objectives were included in the research model. An interesting extension would be to include other constructs which may be determinant in the relationship between corporate image, corporate reputation and customer loyalty. In addition, since our results show that corporate image and reputation play an important role in establishing relationships with customers, the dynamics of these effects should be explored. A longitudinal study could show how the importance of both corporate image and reputation evolves in a customer's relationship to a company. Furthermore, given the great diversity of service industries, it would be helpful to carry out similar studies in other service settings. This would contribute to extending the knowledge base regarding customer loyaltyformation.

\section{Acknowledgments}

This research was funded by the FPU Scholarship Program provided by the Spanish Ministry of Education, Culture and Sports. The authors would like to thank the Center for Business Ethics (Bentley University) for all its help and support.

\section{References}


Abratt, R. (1989) "A new approach to corporate image management process", Journal of Marketing Management, 5(1): 63-76.

Abratt, R. and Kleyn, N. (2012) "Corporate identity, corporate branding and corporate reputations: Reconciliation and integration", European Journal of Marketing, 46(7): 1048-1063.

Ahearne, M., Jelinek, R. and Rapp, A. (2005) "Moving beyond the direct effect of SFA adoption on salesperson performance: Training and support as key moderating factors". Industrial Marketing Management, 34(4):379-388.

Anderson, J.C. and Gerbing, D.W. (1988) "Structural equation modelling in practice: A review and recommended two-step approach". Psychological Bulletin, 103(3):411-423.

Andreassen, T. and Lindestad, B. (1998) "The effects of corporate image in the formation of customer loyalty". Journal of Service Marketing, 1:82-92.

Balmer, J.M.T. (2001) "From the pentagon: A new identity framework". Corporate Reputation Review, 4(1):11-21.

Balmer, J.M.T. and Greyser, S.A. (2003) Revealing the corporation. Perspectives on identity, image, reputation, corporate branding and corporate-level marketing. Routledge, London.

Balmer, J.M.T. and Greyser, S.A. (2006) "Corporate marketing: Integrating corporate identity, corporate branding, corporate communications, corporate image and corporate reputation", European Journal of Marketing, 40(7):730-741.

Barich, H.P. and Kotler, A. (1991) "Framework for marketing image management". Sloan Management Review, 94:94-104.

Bentler, P.M. (1992) "On the fit of models to covariances and methodology to the Bulletin”. Psychological Bulletin, 112:400-404.

Bentler, P.M. and Bonnett, D.G. (1980) "Significance tests and goodness of fit in the analysis of covariance structures". Psychological Bulletin, 88:588-606.

Berens, G. and van Riel, B.M. (2004) "Corporate associations in the academic literature: Three main streams of thought in the reputation measurement literature". Corporate Reputation Review, 7(2):161-178.

Bigné, J.E., Sánchez, M.I. and Sánchez, J. (2000) “Tourism image, evaluation variables and alter purchase behavior: Inter-relationship". Tourism Management, 22:607-623. 
Carrasco, I.B., Salinas, E.M. and Pérez, J. (2008) "Extensiones de marca en bienes y servicios: Evaluación y efectos sobre la imagen de marca”. Revista Española de Investigación de Marketing ESIC, 12(2):25-43.

Chaudhuri, A. and Holbrook, M. (2001) "The chain of effects from brand trust and brand affect to brand performance: The role of brand loyalty". Journal of Marketing, 65(2):81-93.

Cretu, A. and Brodie, R.J. (2007) "The influence of brand image and company reputation where manufacturers market to small firms: A customer value perspective". Industrial Marketing Management, 36(2):230-240.

Dichter, E. (1985) “What's in an image”. Journal of Consumer Marketing, 2(1):75-81.

Dick, A. and Basu, K. (1994) "Customer loyalty: Towards an integrated framework". Journal of the Academy of Marketing Science, 22(2):99-113.

Dowling, G.R. (1988) "Measuring corporate images: A review of alternative approaches". Journal of Business Research, 17:27-34.

Dowling, G.R. and Uncles, M. (1997) "Do customer loyalty programs really work?" Sloan Management Review, 38(4): 71-82.

Dowling, G.R. (2006) "Reputation risk: It's the board's ultimate responsibility". Journal of Business Strategy, 27(2): 59-68.

Fombrun, C.J. (1996) Reputation: Realizing value from the corporate image. Harvard Business School Press.

Fombrun, C. J., and van Riel, C. (1997) "The reputational landscape". Corporate Reputation Review, 1(2):5-13.

Fombrun, C. and Shanley, M. (1990) "What's in a name? Reputation building and corporate strategy". Academy of Management Journal, 33:233-258.

Fombrun, C. J., Gardberg, N. A., and Sever, J. W. (2000) "The reputation quotient: A multi-stakeholder measure of corporate reputation". The Journal of Brand Management, 7(4): 241-255.

Franklin, A. (1984) "Reputation and product quality". Rand Journal of Economics, 15:3 311-327.

Gilly, M.C. and Zeithaml, V.A. (1985) "The elderly consumer and adoption of technologies". Journal of Consumer Research, 12:353-357.

Gotsi, M. and Wilson, A. (2001) "Corporate reputation management: Living the brand". Management Decision, 39(2):99-116. 
Greyser, S.A. (1999) “Advancing and enhancing corporate reputation”. Corporate Communications: An International Journal, 4(4):177-181.

Hair, J.F., Black, W.C., Babin, B.J. and Anderson, R.E. (2010) Multivariate Data Analysis. Pearson Prentice-Hall: Upper Saddle River.

Hardaker, S. and Fill, C. (2005) "Corporate service brands: The intellectual and emotional engagement of employees". Corporate Reputation Review, 7(4):365-376.

Helm, S. (2005) "Designing a formative measure for corporate reputation". Corporate Reputation Review, 8(2):95-109.

Helm, S. and Tolsdorf, J. (2013) "How does corporate reputation affect customer loyalty in a corporate crisis?". Journal of Contingencies and Crisis Management, 21: 144-152.

INE, Spanish Institute of Statistics (2012) Encuesta de ocupación hotelera. http://www.ine.es/jaxi/menu.do?type=pcaxis \&path=/t11/e162eoh/a2011\&file $=p$ $\underline{\text { caxis }}$

Keh, H. T. and Xie, Y. (2009) "Corporate reputation and customer behavioral intentions: The roles of trust, identification and commitment". Industrial Marketing Management, 38(7): 732-742.

Kennedy, S.H. (1977) "Nurturing corporate images: Total communication or ego trip?" European Journal of Marketing, 11(3):120-164.

Kotler, P. and Gertner, D. (2002) "Country as brand, product, and beyond: A place marketing and brand management perspective". Journal of Brand Management, 9(62): 249-261.

Lam, S.Y., Shankar, V., Erramilli, M.K. and Murthy, B. (2004) "Customer value, satisfaction, loyalty and switching costs: An illustration form a business-tobusiness service context". Journal of the Academy Marketing Science, 32(3):293-311.

Martínez, P. and Rodríguez del Bosque, I. (2013) “CSR and customer loyalty: The roles of trust, customer identification with the company and satisfaction". International Journal of Hospitality Management, 35:89-99.

Melewar, T. C., Sarstedt, M. and Hallier, C. (2012) "Corporate identity, image and reputation management: A further analysis", Corporate Communications: An International Journal, 17(1): 50-53.

Mudambi, S.M., Doyle, P. and Wong, V. (1997) "An exploration of branding in industrial markets". Industrial Marketing Management, 26:433-446. 
Nguyen, N. and Leblanc, G. (2001) "Corporate image and corporate reputation in customers' retention decisions in services". Journal of Retailing and Consumer Services, 8:227-236.

Nguyen, N. and Leblanc, G. (2002) "Contact personnel, physical environment and the perceived corporate image of intangible services by new clients". International Journal of Service Industry Management, 13(3):242-262.

Oliver, R.L. (1997) Satisfaction: A behavioral perspective on the consumer. New York: McGraw-Hill.

Park, H.S. (2006) "The relationship between brand loyalty and financial performance: An empirical study on the hotel industry in Las Vegas". University of Nevada, Las Vegas, UMI Dissertations Publishing.

Petrick, J. F. (2004) “Are loyal visitors desired visitors?”. Tourism Management, 25(4): 463-470.

Porter, M. (1985) Competitive Advantage. Free Press, New York.

Reichheld, F.F. (1993) "Loyalty-based management". Harvard Business Review, 71: 64-73.

Reichheld, F.F. and Sasser W.E. (1990) "Zero defections: quality comes to services". Harvard Business Review, 68:105-111.

Reichheld, F.F., Robert, G.M. and Christopher, H. (2000) "E-customer Loyalty: Applying the traditional rules of business for online success". European Business Journal, 12(4):173-179.

Richard, J.E. and Zhang, A. (2012) "Corporate image, loyalty, and commitment in the consumer travel industry”. Journal of Marketing Management, 28(5/6): 568-593.

Rindova, V.P. and Fombrun, C.J. (1999) "Constructing competitive advantage: The role of firm constituent interactions”. Strategic Management Journal, 20:691-710.

Rindova, V. P., Williamson, I. O., Petkova, A. P. and Sever, J. M. (2005) "Being good or being known: An empirical examination of the dimensions, antecedents, and consequences of organizational reputation". Academy of Management Journal, 48: 1033-1049.

Roberts, P.W. and Dowling, G.R. (2002) "Corporate reputation and sustained superior financial performance”, Strategic Management Journal, 23:1077-1093.

Rust, R.T., Lemon, K.N. and Narayandas, D. (2004) "Return on marketing: Using customer equity to focus marketing strategy". Journal of Marketing, 68:109-127.

Sirdeshmukh, D., Japdig, S. and Berry, S. (2002) "Customer trust, value, and loyalty in relational exchanges”. Journal of Marketing, 66:15-37. 
Trespalacios, J.A., Vázquez, R. and Bello, L. (2005) Investigación de Mercados. Thompson, Madrid.

Tu, Y.T., Li, M.L. and Chih, H.C. (2013) "An empirical study of corporate brand image, customer perceived value and satisfaction on loyalty in shoe industry". Journal of Economics and Behavioral Studies, 5(7): 469-483.

Uncles, M.D.; Dowling, G.R. and Hammond, K. (2003) "Customer loyalty and customer loyalty programs”, Journal of Consumer Marketing, 20(4): 294-316.

UNWTO, United Nations World Tourism Organization (2009). Barómetro OMT del Turismo Mundial, 6(3): http://www.unwto.org/facts/eng/pdf/barometer/UNWTOBarom083spLR.pdf

Walsh, G. and K.P. Wiedmann (2004) "A conceptualization of corporate reputation in Germany: An evaluation and extension of the RQ", Corporate Reputation Review, 6:304-312.

Walsh, G. and Beatty, S. R. (2007) "Customer-based corporate reputation of a service firm: Scale development and validation", Journal of the Academy Marketing Science, 35:127-143.

Walsh, G., Mitchell, V.W., Jackson, P.R. and Beatty, S.R. (2009) "Examining the antecedents and consequences of corporate reputation: A customer perspective". British Journal of Management, 20(2):187-203.

Wang, Y., Lo, H.P. and Hui, Y.V. (2003) "The antecedents of service quality and product quality and their influence on bank reputation: Evidence from the banking industry in China". Managing Service Quality, 13(1):72-83.

Weiwei, T. (2007) "Impact of corporate image and corporate reputation on customer loyalty: A review”, Management Science and Engineering, 1(2):57-62.

Whetten, D.A. and Mackey, A. (2002) "Identity congruence and its implications for the study of organizational reputation”. Business \& Society, 41:393-414.

Yoon, E., Guffey, H.G. and Kijewski, V. (1993) "The effects of information and company reputation on intentions to buy a business service". Journal of Business Research, 27: 215-228.

Yeung, M.C. and Ennew, C.T. (2000) "From customer satisfaction to profitability". Journal of Strategic Marketing, 8:313-326.

Zeithaml, V.A., Berry, L.L. and Parasuraman, A. (1996) "The behavioral consequences of service quality". Journal of Marketing, 60: 31-46.

Zinkhan, G.M., Ganesh, J., Jaju, A. and Hayes, L. (2001) Corporate image: A conceptual framework for strategic planning. In: Marshall, G.W., Grove, S.J. 
(Eds.), Conference Proceedings, 12. American Marketing Association, Chicago, IL, 152-159.

Appendix here 